\title{
Protocolo de cooperação fonoaudiológica para avaliação nasofibrolaringoscópica da mobilidade laríngea em doenças da tireóide (PAN)***
}

\author{
Speech-language cooperation protocol for the fiberoptic \\ laryngoscopy evaluation of larynx mobility
}

Priscila Esteves Ciocchi*

Claudia Regina Furquim de Andrade**

*Fonoaudióloga. Mestre em Ciências da Reabilitação pela Faculdade de Medicina da Universidade de São Paulo. Endereço para correspondência: Rua Dr. Paschoal Imperatriz, 114 Apto. 222 B - São Paulo - SP CEP 04705-070 (priciocchi@hotmail.com).

**Fonoaudióloga. Professora Titular do Departamento de Fisioterapia, Fonoaudiologia e Terapia Ocupacional da Faculdade de Medicina da Universidade de São Paulo.

***Trabalho Realizado no Laboratório de Investigação Fonoaudiológica da Fluência, Motricidade e Funções Orofaciais do Departamento de Fisioterapia, Fonoaudiologia e Terapia Ocupacional da Faculdade de Medicina da Universidade de São Paulo.

Artigo Original de Pesquisa

Artigo Submetido a Avaliação por Pares

Conflito de Interesse: não

Recebido em 15.05.2008

Revisado em 05.01.2009.

Aceito para Publicação em 03.02.2009.

\begin{abstract}
Background: voice protocol. Aim: to propose a protocol for the fiberoptic laryngoscopy evaluation of larynx mobility in thyroid illnesses (PAN), with the intention of having an objective, precise and consensual instrument for this assessment. Method: the first version of the protocol was elaborated based on data found in the literature; the protocol was judged twice, using the triangulation method; a pilot version was presented and applied in 11 patients; it was then judged again by doctors and speech-language pathologists; based on the analysis of the judges and after the application of the pilot version, the final version of the PAN was proposed. Results: the final protocol was composed by two parts. The first part, considered a standard procedure, is composed by 4 essential items that necessarily should be evaluated: normal inspiration; forced inspiration; vowel /é/ isolated and sustained; and sharp vowel /i/, isolated and sustained. The second part, considered a speech-language complementation, is composed by items that should be understood as being important for speech-language pathologists as they are informative or predictive of the effectiveness of therapy: vowel /é/ sustained and weak; vowel /é/ sustained and sharp; vowel /é/ sustained and deep; vowel /é/ short with abrupt vocal onset. Conclusions: the PAN, in its final version, contributes for the systematization of the assessment procedures based on evidence and on the agreement of professionals. The PAN results in the description of items to be obtained during medical and speech-language assessment during the fiberopticlaryngoscopy evaluation of larynx mobility in thyroid illnesses.
\end{abstract}

Key Words: Protocol; Laryngoscopy; Thyroidectomy; Vocal Cord Paralysis; Vocal Alterations.

Resumo

Tema: protocolo de avaliação da voz. Objetivo: proposição de um protocolo de cooperação fonoaudiológica para avaliação nasofibrolaringoscópica da mobilidade laríngea em doenças da tireóide (PAN), visando a composição de um instrumento objetivo, preciso e consensual para avaliação. Métodos: a primeira versão do protocolo foi elaborada a partir de fundamentação bibliográfica; o PAN foi julgado em duas instâncias pelo método de triangulação por seis juízes em três etapas; foi constituída uma versão piloto do protocolo e aplicada em 11 pacientes; houve novo julgamento de médicos e fonoaudiólogos; a partir da concordância dos juízes, após a aplicação do piloto, foi construída a versão final do PAN. Resultados: o PAN final foi composto por duas partes. A primeira parte considerada o procedimento padrão composta por 4 itens imprescindíveis e que devem necessariamente ser avaliados são: inspiração normal; inspiração forçada; vogal /é/ isolada e sustentada e vogal /i/ aguda isolada e sustentada. A segunda parte considerada de complementação fonoaudiológica é composta pelos itens que são entendidos pelos fonoaudiólogos como fatores informativos ou preditivos para a eficácia da terapia. Esses itens são: vogal /é/ sustentada e fraca; vogal /é/ sustentada e aguda; vogal /é/ sustentada e grave; vogal /é/ curta com ataque vocal brusco. Conclusões: o PAN, em sua versão final, contribui para a sistematização dos procedimentos de avaliação fundamentados em evidências e concordâncias profissionais. O PAN resulta na descrição de itens a serem solicitados durante a avaliação médica e fonoaudiológica no exame de nasofibrolaringoscopia da alteração da mobilidade laríngea em doenças da tireóide.

Palavras-Chave: Protocolo; Laringoscopia; Tireoidectomia; Paralisia Laríngea; Alterações Vocais.

Referenciar este material como:

A. Ciocchi PE, Andrade CRF. Speech-language cooperation protocol for the fiberoptic laryngoscopy evaluation of larynx mobility (original title: Protocolo de Z cooperação fonoaudiológica para avaliação nasofibrolaringoscópica da mobilidade laríngea em doenças da tireóide (PAN)). Pró-Fono Revista de Atualização Científica. 2009 jan-mar;21(1):31-8. 


\section{Introduction}

The thyroid gland produces the hormones T3 (triiodothyronine) and $\mathrm{T} 4$ (thyroxine) which are responsible for methabolism regulation 1 . It is a single endocrine secretion organ located at the median region of the neck. It involves the larynx and the trachea as a ring 2-3.

The thyroidectomy - partial or total withdrawal of the thyroid gland - is a surgery indicated and utilized, according to Surgeons, for the removal of both benign and malignant nodules of thyroid 1-2, 4-5.

Thyroid disorders have high prevalence in general population, and most of the cases occur in women 3-4. In the United States about 80,000 thyroid surgeries are conducted each year 4 .

The recurrent laryngeal nerve injury during the thyroidectomy is responsible for almost $40 \%$ of laryngeal mobility alterations 1-3,9-11. Signs and symptoms of laryngeal immobility might vary according to the positions of the vocal folds and according to the functioning of vocal tract structures, requiring a specific evaluation and rehabilitation process with a Speech-Language Pathologist 5-8.

The flexible laryngoscopy is a quite indicated method for the evaluation of post operatory thyroidectomies, presenting effectiveness in almost $100 \%$ of the cases, even under adverse anatomical conditions such as trismus or exacerbated nausea reflex. This test allows accurate assessment of the upper airways, hypopharynx structures and all areas of the larynx.

In addition to provide the static evaluation of these structures, this technique makes the analysis of functional activities during speech movements, crying and swallowing possible 12-28.

The purpose of this study was to propose a Protocol of Speech-Language Pathology cooperation for the fiberoptic laryngoscopy evaluation of larynx mobility (PAN) in thyroid disorders. The PAN is proposed as an objective protocol for assessing the functionality of larynx and vocal tract. It should be used prior and after Speech-Language Pathology treatment, thus enabling the analysis and definition of conduct based on objective measures. It is considered a protocol of cooperation, because its implementation in nasofibrolaryngoscopy is carried through by a diverse range of healthcare professionals.

\section{Methods}

The study was approved by regulatory committees of research involving human subjects under Protocol number 938/06.
Initially the PAN was elaborated based on clinical experience and on a literature review comprised by 88 references being: $58 \%$ journals (45.5\% of them from the last five years) and $42 \%$ of specific and fundamental articles on the area.

In the second phase, PAN was judged in three stages by six judges, three Speech-Language Pathologists with Doctoral Degree and specialization in the area of voice and three Head and Neck Surgeons with experience in laryngoscopy.

Evaluation items for which the level of agreement among the judges reached the minimum of $67 \%$ were maintained in the pilot version of the PAN. Modifications or additions suggested by judges whose levels of agreement reached $67 \%$ were also added to this pilot version (Appendix).

The PAN, in the pilot version, was applied in eleven subjects that were submitted to thyroidectomy (partial or total), with six subjects presenting alterations in vocal folds mobility and five subjects without mobility alteration.

All participants were female; adults (over 18 years) and patients of the Department of the Head and Neck Surgery. The examinations were performed at the same Department by the responsible Surgeons.

The nasofibrolaryngoscopic used on this study was a Welch Allyn, with $4 \mathrm{~mm}$ flexible fibroscopy, model RL-100 and serial number A01638 Japan, with recording system direct on the computer. The results obtained on the nasofibroscopy were not compared to laryngeal estroboscopy - which could provide more precise data concerning the vibration of the vocal folds mucosa - because this examination is not performed as a routine service where the study was conducted.

The inclusion criteria of participants for the pilot study followed medical guidelines: patients with thyroid disorder, previously diagnosed by a Head and Neck Surgeon who had performed thyroidectomy for removal of tumor which evolved or not to laryngeal mobility alteration. The medical exclusion criteria were: previous treatment of head and neck tumors, radiotherapy, chemotherapy, nasogastric tube, neck dissection, neurological disorders and cognitive deficits.

\section{Results}

Two tables were initially designed in order to analyze the efficience of the pilot PAN application.

Table 1 presents items considered valid and essential by Surgeons for the assessment of 
laryngeal mobility (the protocol was filled concomitantly to evaluation).

Table 2 presents the items considered by Speech-Language Pathologists as valid and essential to the assessment of laryngeal mobility. (The protocol was filled while the judges watched the tape recordings of the examination. This type of measure was necessary in order to avoid accumulation of people at the time of testing which could impair the visibility of the analyzed material). The judges of this phase were not the same from the initial phases of the study in order to guarantee a previous knowledge free judgment.

Preliminary results were subjected to statistical analysis. For the data analysis, one point was attributed for each "yes" response and zero point for each "no" response. With the purpose to establish whether the groups (Surgeons and Speech-Language Pathologists) differentiate on total score the Mann-Whitney test with significance level of $5 \%$ was used.

As observed on the Mann-Whitney test, the groups did not differ on the total score (Surgeons, median 7.00; Speech-Language Pathologists median 11.00; W 230.0; p-value 0,169). Thus, both the groups presented a consistent behavior on the judgments.
Chi-square tests were used to verify whether the groups presented a similar pattern of responses regarding the necessity or not of inclusion of each item on the protocol. The calculation was made from $2 \times 2$ tables and the number of degrees of freedom was equal to one.

Table 3 shows the chi-square value and the pvalue for each of the comparisons. For some tasks, it was not possible to calculate Chi-Squares because the groups had presented identical responses. According to the exposed in Table 3, items 1, 2, 3, 4 and 6 were identical for both groups, once they were accepted by $100 \%$ of

medical professionals and Speech-Language Pathologists. Items 5, 7 and 8 tended to differentiate: all Speech-Language Pathologists had accepted these items while not all Surgeons agreed with their permanence. The groups differed on the questions number nine to sixteen. The questions numbered from nine to twelve were accepted by $100 \%$ of Speech-Language Pathologists while not all Surgeons agreed with their permanence on the protocol.

With regards to questions issues 13 to 16 , they were accepted by a proportion of Surgeons while all Speech-Language Pathologists did not see the need for the permanence of such items.

TABLE 1. Items considered essential by physicians after examinations.

\begin{tabular}{|c|c|c|c|c|c|c|c|c|c|c|c|c|}
\hline Tasks/Subjects & S1 & $\mathrm{S} 2$ & S3 & S4 & S5 & S6 & S7 & S8 & S9 & $\mathrm{S} 10$ & $\mathrm{~S} 11$ & $\%$ concordance \\
\hline 1. Normal Inhale & $\bar{X}$ & $\bar{X}$ & $\bar{X}$ & $\bar{X}$ & $\mathrm{X}$ & $\mathrm{X}$ & $\mathrm{X}$ & $\bar{X}$ & $\mathrm{X}$ & $\mathrm{X}$ & $\mathrm{X}$ & 100 \\
\hline 2. Effort Inhale & $\mathrm{X}$ & $\mathrm{X}$ & $\mathrm{X}$ & $\mathrm{X}$ & $\mathrm{X}$ & $\mathrm{X}$ & $\mathrm{X}$ & $\mathrm{X}$ & $\mathrm{X}$ & $\mathrm{X}$ & $\mathrm{X}$ & 100 \\
\hline 3. Isolated and sustained & & & & & & & & & & & & \\
\hline $\begin{array}{l}\text { vowel /é/ (laryngeal mobility } \\
\text { and vocal fold position) }\end{array}$ & $\mathrm{X}$ & $\mathrm{X}$ & $\mathrm{X}$ & $\mathrm{X}$ & $\mathrm{X}$ & $\mathrm{X}$ & $\mathrm{X}$ & $\mathrm{X}$ & $\mathrm{X}$ & $\mathrm{X}$ & $\mathrm{X}$ & 100 \\
\hline $\begin{array}{l}\text { 4. Isolated and sustained } \\
\text { vowel /é/ (vocal fold, median } \\
\text { vestibular and Antero- } \\
\text { posterior constriction) }\end{array}$ & $\mathrm{X}$ & $\mathrm{X}$ & $\mathrm{X}$ & $\mathrm{X}$ & $\mathrm{X}$ & $\mathrm{X}$ & $\mathrm{X}$ & $\mathrm{X}$ & $\mathrm{X}$ & $\mathrm{X}$ & $\mathrm{X}$ & 100 \\
\hline 5. Cough & $\mathrm{X}$ & & $\mathrm{X}$ & & $\mathrm{X}$ & & $\mathrm{X}$ & $\mathrm{X}$ & $\mathrm{X}$ & $\mathrm{X}$ & $\mathrm{X}$ & 72,7 \\
\hline $\begin{array}{l}\text { 6. Isolated and sustained high } \\
\text { pitch vowel /i/ }\end{array}$ & $\mathrm{X}$ & $\mathrm{X}$ & $\mathrm{X}$ & $\mathrm{X}$ & $\mathrm{X}$ & $\mathrm{X}$ & $\mathrm{X}$ & $\mathrm{X}$ & $\mathrm{X}$ & $\mathrm{X}$ & $\mathrm{X}$ & 100 \\
\hline 7. Counting from 1 to 10 & & $\mathrm{X}$ & & $\mathrm{X}$ & $\mathrm{X}$ & $\mathrm{X}$ & $\mathrm{X}$ & $\mathrm{X}$ & $\mathrm{X}$ & $\mathrm{X}$ & $\mathrm{X}$ & 81,8 \\
\hline $\begin{array}{l}\text { 8. Isolated and sustained } \\
\text { strong vowel /é/ }\end{array}$ & $\mathrm{X}$ & $\mathrm{X}$ & $\mathrm{X}$ & & & & $\mathrm{X}$ & $\mathrm{X}$ & $\mathrm{X}$ & $\mathrm{X}$ & $\mathrm{X}$ & 72,7 \\
\hline $\begin{array}{l}\text { 9. Isolated and sustained } \\
\text { weak vowel/é/ }\end{array}$ & & & & & & & $\mathrm{X}$ & $\mathrm{X}$ & $\mathrm{X}$ & $\mathrm{X}$ & $\mathrm{X}$ & 45,45 \\
\hline $\begin{array}{l}\text { 10. Isolated and sustained } \\
\text { high pitch vowel /é/ }\end{array}$ & & $\mathrm{X}$ & & & & & $\mathrm{X}$ & $\mathrm{X}$ & $\mathrm{X}$ & $\mathrm{X}$ & $\mathrm{X}$ & 54,5 \\
\hline $\begin{array}{l}\text { 11. Isolated and sustained } \\
\text { low pitch vowel /é/ }\end{array}$ & & $\mathrm{X}$ & & & & & $\mathrm{X}$ & $\mathrm{X}$ & $\mathrm{X}$ & $\mathrm{X}$ & $\mathrm{X}$ & 54,5 \\
\hline $\begin{array}{l}\text { 12.Short vowel /é/ with vocal } \\
\text { attack }\end{array}$ & $\mathrm{X}$ & & & & & & $\mathrm{X}$ & $\mathrm{X}$ & $\mathrm{X}$ & $\mathrm{X}$ & $\mathrm{X}$ & 54,5 \\
\hline $\begin{array}{l}\text { 13. Vowel /é/ with head } \\
\text { inclined to the right shoulder }\end{array}$ & $\mathrm{X}$ & $\mathrm{X}$ & $\mathrm{X}$ & & & & $\mathrm{X}$ & & & & $\mathrm{X}$ & 45,45 \\
\hline $\begin{array}{l}\text { 14. Vowel /é/ with head } \\
\text { inclined to the left shoulder }\end{array}$ & $X$ & $X$ & X & & & & $X$ & & & & $\mathrm{X}$ & 45,45 \\
\hline $\begin{array}{l}\text { 15. Vowel /é/ with head } \\
\text { turned to the right side }\end{array}$ & X & X & $X$ & & & & $X$ & & & & $X$ & 45,45 \\
\hline $\begin{array}{l}\text { 16. Vowel/é/ with head } \\
\text { turned to the left side }\end{array}$ & X & X & $X$ & & & & $X$ & & & & X & 45,45 \\
\hline
\end{tabular}


TABLE 2. Items considered essential by Speech Pathologists after examination.

\begin{tabular}{|c|c|c|c|c|c|c|c|c|c|c|c|c|c|}
\hline Tasks/Subjects & S1 & $\mathrm{S} 2$ & S3 & S4 & $\mathrm{S} 5$ & S6 & S7 & 7.58 & \begin{tabular}{l|l}
8 & 59 \\
\end{tabular} & $\mathrm{s1}$ & & 311 & $\%$ \\
\hline 1. Normal Inhale & $x$ & $\mathrm{X}$ & $\mathrm{X}$ & $\mathrm{X}$ & $\mathrm{X}$ & & $\mathrm{x}$ & $x$ & $\mathrm{X}$ & $x$ & $x$ & $\mathrm{X}$ & 100 \\
\hline $\begin{array}{l}\text { 2. Effort Inhale } \\
\text { 3. Isolated and sustained vowel /é/ }\end{array}$ & $x$ & $\mathrm{x}$ & $x$ & $x$ & $x$ & & $x$ & $x$ & $x$ & $\mathrm{x}$ & $x$ & $x$ & 100 \\
\hline $\begin{array}{l}\text { (laryngeal mobility and vocal fold } \\
\text { position) }\end{array}$ & $x$ & $\mathrm{x}$ & $\mathrm{x}$ & $x$ & $x$ & & $x$ & $x$ & $x$ & $x$ & $x$ & $x$ & 100 \\
\hline $\begin{array}{l}\text { 4. Isolated and sustained vowel /é/ } \\
\text { (vocal fold, median vestibular and } \\
\text { Antero-posterior constriction) }\end{array}$ & $\mathrm{X}$ & $\mathrm{x}$ & $x$ & $\mathrm{x}$ & $x$ & & $x$ & $\mathrm{x}$ & $x$ & $x$ & $x$ & $\mathrm{x}$ & 100 \\
\hline 5. Coug & $\mathrm{X}$ & $\mathrm{x}$ & $x$ & $x$ & $\mathrm{X}$ & & $X$ & $\mathrm{X}$ & $x$ & $\mathrm{x}$ & $x$ & $\mathrm{X}$ & 100 \\
\hline $\begin{array}{l}\text { 6. Isolated and sustained high pitch } \\
\text { vowel /i/ }\end{array}$ & $\mathrm{x}$ & $x$ & $x$ & $x$ & $X$ & & $x$ & $x$ & $x$ & $x$ & $x$ & $\mathrm{x}$ & 100 \\
\hline 7. Counting from 1 to 10 & $\mathrm{X}$ & $\mathrm{x}$ & $x$ & $x$ & $X$ & & $x$ & $\mathrm{x}$ & $x$ & $\mathrm{x}$ & $X$ & $\mathrm{x}$ & 100 \\
\hline $\begin{array}{l}\text { 8. Isolated and sustained strong vowel } \\
\text { /é/ }\end{array}$ & $x$ & $x$ & $x$ & $\mathrm{x}$ & $\mathrm{X}$ & & $x$ & $x$ & $x$ & $\mathrm{x}$ & $x$ & $x$ & 100 \\
\hline $\begin{array}{l}\text { 9. Isolated and sustained weak vowel } \\
\text { lé/ }\end{array}$ & $\mathrm{X}$ & $x$ & $x$ & $\mathrm{x}$ & $\mathrm{X}$ & & $x$ & $\mathrm{X}$ & $x$ & $\mathrm{x}$ & $x$ & $\mathrm{x}$ & 100 \\
\hline $\begin{array}{l}\text { 10. Isolated and sustained high pitch } \\
\text { vowel /é/ }\end{array}$ & $x$ & $x$ & $x$ & $\mathrm{x}$ & $\mathrm{X}$ & & $x$ & $x$ & $x$ & $\mathrm{x}$ & $x$ & $x$ & 100 \\
\hline $\begin{array}{l}\text { 11. Isolated and sustained low pitch } \\
\text { vowel/é/ }\end{array}$ & $X$ & $\mathrm{X}$ & $\mathrm{X}$ & $\mathrm{x}$ & $\mathrm{X}$ & & $X$ & $\mathrm{x}$ & $\mathrm{X}$ & $\mathrm{x}$ & $x$ & $\mathrm{X}$ & 100 \\
\hline 12.Short vowel /é/ with vocal attack & $\mathrm{x}$ & $x$ & $x$ & $\mathrm{x}$ & $\mathrm{X}$ & & $X$ & $x$ & $x$ & $\mathrm{x}$ & $x$ & $\mathrm{x}$ & 100 \\
\hline $\begin{array}{l}\text { right shoulder } \\
14 \text {. Vowel /é/ with head inclined to the }\end{array}$ & & & & & & & & & & & & & 0 \\
\hline left shoulder & & & & & & & & & & & & & 0 \\
\hline $\begin{array}{l}\text { 15. Vowel /é/ with head turned to the } \\
\text { right side }\end{array}$ & & & & & & & & & & & & & 0 \\
\hline $\begin{array}{l}\text { 16. Vowel lé/ with head turned to the } \\
\text { left side }\end{array}$ & & & & & & & & & & & & & 0 \\
\hline
\end{tabular}

TABLE 3. Chi-Square Test

\begin{tabular}{|c|c|c|}
\hline & $\mathrm{X}^{2}$ & $\mathrm{p}$-value \\
\hline 1. Normal Inhale & & $\#$ \\
\hline 2. Effort Inhale & & \# \\
\hline 3. Isolated and sustained vowel /é/ (laryngeal mobility and vocal fold position) & & \# \\
\hline $\begin{array}{l}\text { 4. Isolated and sustained vowel /é/ } \\
\text { (vocal fold, median vestibular and Antero-posterior constriction) }\end{array}$ & & \# \\
\hline 5. Cough & 3,474 & 0,062 \\
\hline 6. Isolated and sustained high pitch vowel /i/ & & \# \\
\hline 7. Counting from 1 to 10 & 2,200 & 0,138 \\
\hline 8. Isolated and sustained strong vowel /é/ & 3,474 & 0,062 \\
\hline 9. Isolated and sustained weak vowel /é/ & 8,250 & $0,004 *$ \\
\hline 10. Isolated and sustained high pitch vowel/é/ & 6,471 & $0,011^{*}$ \\
\hline 11. Isolated and sustained low pitch vowel /é/ & 6,471 & $0,011^{*}$ \\
\hline 12.Short vowel /é/ with vocal attack & 6,471 & $0,011 *$ \\
\hline 13. Vowel /é/ with head inclined to the right shoulder & 8,250 & $0,004 *$ \\
\hline 14. Vowel /é/ with head inclined to the left shoulder & 8,250 & $0,004 *$ \\
\hline 15. Vowel /é/ with head turned to the right side & 8,250 & $0,004 *$ \\
\hline 16. Vowel /é/ with head turned to the left side & 8,250 & $0,004 *$ \\
\hline
\end{tabular}

\#: groups presented identical responses. 


\section{Discussion}

According to the literature 4, 9-10, 14-15, 21, 23, 25 , the vocal tract should be evaluated before and after the thyroid surgery in order to detect possible previous alterations and in order to evaluate the characteristics of both anatomy and physiology of this region pre and post-surgical treatment.

As already pointed in the introduction of this study, there is no consensus on which items should be addressed on evaluation, specifically on nasofibroscopy, for the evaluation of laryngeal mobility of patients undergoing thyroidectomy. There is also no consensus on which items of assessment could be considered within the examination.

The present study indicates that the necessary and indispensable items are: normal inspiration (aiming the removal of the vocal folds in breath at rest); forced inspiration (aiming the maximum dislocation of the vocal folds in forced breathing); isolated and sustained vowel /é/ (aiming laryngeal mobility and the positioning of vocal folds); isolated and sustained vowel/é/ (aiming the constriction of the vocal folds, median and antero-posterior vestibular as well as glottic closure) and sustained and sharp vowel / $\mathrm{i} /$ (aiming the stretching of the vocal folds and, thus, the stretching of the cricothyroid muscle).

The study also indicates that there are items that are not usually assessed, but are seen by Speech-Language Pathologists as important and informative as predictive factors for therapy effectiveness. These items are: sustained and weak vowel /é/ (targeting the larynx coaptation with minimal subglottic pressure through vestibular, median, and anterior-posterior constriction of voca fold); sustained and sharp vowel /é/ (targeting the vestibular and anterior-posterior constrictions of vocal fold along with the action of the cricothyroid muscle); sustained and deep vowel /é/ (targeting the vestibular median and anterior-posterior constriction of vocal fold along with the action of thyroarytenoid muscle); short with abrupt vocal onset vowel /é/ (seeking the hyperactivity of vocal folds and / or median vestibular fold while performing a task with phonatory effort).

The present study indicates the existence of controversial items $(5,7-8,13-16)$ that are raised as valid by some practitioners and as irrelevant by others. These items should be considered with caution and should, therefore, be further investigated on their need or not to be included on a protocol as PAN.

Differences were observed on questions and tasks judged as fundamentals by Surgeons and by

Speech-Language Pathologists. It is believed that these differences are due to different backgrounds and focus that each professional has in his/her clinical practice. The Surgeons focused mainly on the injury itself (in change of laryngeal mobility), while Speech-Language Pathologists focused such on the injury as, more specifically, on the laryngeal physiology.

\section{Conclusion}

The objective of the PAN, in its final version, is to contribute to systematic assessment procedures based on evidence and professional agreements. It is necessary for the professional to act on a comproved manner. To base on specific protocols permeates these aspects and allows the professional to act on a planned manner, documenting the processes, and sedimenting and evaluating their practice and working patterns.

The PAN is based on a theoretical and practical proposition, besides judged evaluations. It resulted on the description of the items to be requested during medical and Speech-Language Pathology nasofibrolaryngoscopy evaluation on the alteration of laryngeal mobility in thyroid diseases. Thus, the PAN intends to be an objective and standardized, instrument aiming to assist Surgeons and SpeechLanguage Pathologists on a consistent professional practice, giving support for the evaluation and subsequent rehabilitation, full recovery and improvement in life quality of the patient. 


\section{References}

1. Harold E. Anatomy of he thyroid and parathyroidglands, Surgery (Oxford). 2007;25(11):467-8.

2. Myssiorek D. Recurrent laryngeal nerve paralysis: Anatomy and Etiology. Otolaryngol Clin North Am. 2004;37:25-44.

3. Ferraz AR, Cernea CR, Araújo Filho VJF, Turcano R. Complicações de Tireoidectomias. Rev Brasileira de Cirurgia de Cabeça e Pescoço. 2003;32(3):31-3.

4. Bhattacharyya N, Fried MP. Assessment of the morbidity and complications of total thyroidectomy. Arch Otolaryngol Head Neck Surg. 2002;128:389-92.

5. Gonçalves FJ, Kowalski LP. Surgical complications after thyroid surgery performed in a cancer hospital. Otolaryngol Head Neck Surg. 2005;132:490-4.

6. Arakawa-Segueno L. Voz e deglutição de pacientes com e sem mobilidade laríngea após tireoidectomia (Tese). São Paulo: Departamento de Clínica Cirúrgica. Faculdade de Medicina da Universidade de São Paulo; 2008.

7. Behlau M, Pontes P. Exame Laringológico. In: Behlau M, Pontes P. Avaliação e Tratamento das Disfonias. São Paulo: Lovise; 1995. p. 143-66.

8. Bhuta T, Patrick L, Garnett JD. Perceptual evaluation of voice quality and its correlation with acoustic measurements. J Voice. 2004;18:299-304.

9. Colton R, Casper J. Understanding voice problems. A physiological perspective for diagnosis and treatment. 2 th ed. Baltimore: Williams \& Wilkins; 1998.

10. Netto IP. Laringe, voz e deglutição pré e póstireoidectomia (Dissertação). São Paulo: Departamento de Oncologia. Fundação Antônio Prudente; 2005.

11. Ruiz DMC, Richieri-Costa A. Paralisias laríngeas unilaterais em diferentes faixas etárias e suas correlações com a etiologia e configuração laríngea (tese). Bauru: Unid HRAC; 2003.

12. Richardson BE, Bastian RW. Clinical Evaluation of Vocal Fold Paralysis. Otolaryngol Clin N Am. 2004;37:4558 .

13. Meek P, Carding PN, Howard DH, Lennard TW. Voice Change Following Thyroid and Parathyroid Surgery. J. Voice. 2007; 14:23-32.

14. Rosato L, Carvelato MT, Toma G De, Avenia N. Recurrent laryngeal nerve damage and phonetic modifications after total thyroidectomy: surgical malpractice only or predictable sequence? World J Surg. 2005;29:780-4.

15. Nemr K, Lehn C. Voz em Câncer de Cabeça e Pescoço In: Ferreira, LP, Befi-Lopes D, Limongi SCO. Tratado de Fonoaudiologia. São Paulo: Roca; 2004. p. 102-17.
16. Musholt TJ, Musholt PB, Garn J, Napiontek U, Keilmann A. Changes of the speaking and singing voice after thyroid or parathyroid surgery. Surg, 2006;140(6):978-88

17. Lacoste L, Karayan J, Lehuedé MS, Thomas D, GoudouSinha M, Ingrand P, et al. A Comparison of Direct, Indirect, and Fiberoptic Laryngoscopy to Evaluate Vocal Cord Paralysis after Thyroid Surgery. Thyroid. 1996;6(1):17-

18. Costa Hoo. Laringoscopia Direta. In: Campos CAH, Costa Hoo. Tratado de Otorrinolaringología. São Paulo: Roca; 2003. p. 351-6.

19. Roehm PC, Rosen C. Dynamic voice assessment using flexible laryngoscopy - how I do it: a target problem and it's solution. American Journal of Otolaryngology. 2004;25(2):138-41.

20. Ferrag TY. The utility of Evaluation True Vocal Fold Motion Before Thyroid Surgery. The Laryngoscope. 2006;2:116-20

21. Schindler A, Bottero A, Capaccio P, Ginocchio D, Adorni F, Ottaviani F. Vocal Improvement After Voice Therapy in Unilateral Vocal Fold Paralysis. J Voice. 2008;22(1):113-8.

22. Meredydd LH, Murray M. The role of stroboscopy in the management of a patient with a unilateral vocal fold paralysis. The Journal of Laryngology and Otology. 1996;110:141-3.

23. Koschkee DL, Rammage L. Voice care in the medica setting. San Diego: Singular, 1997; In: Voz: Livro do Especialista. Behlau M. São Paulo: Lovise; 2001. p. 21421

24. Ciocchi PE, Arakawa-Sugueno L, Andrade CRF, Sampaio C, Kulcsar MA, Ferraz A et al. Comportamento laríngeo durante emissão do "a" curto com ataque vocal brusco e "i" sustentado na paralisia laríngea. In: Anais do XX Congresso Brasileiro de Cirurgia de Cabeça e Pescoço e V Congresso Brasileiro de Fonoaudiologia em Cabeça e Pescoço; Salvador; 2005 .

25. Fleischer S, Schade G, Hess MM. Office-Based Laryngoscopic Observations of Recurrent Laryngeal Nerve Paresis and Paralysis. Otology, Rhinology \& Laryngology. 2005;114(6):488-93

26. Hirano M, Bless D. Videostroboscopic examination of the larynx. San Diego: Singular, 1993. In: Voz: Livro do Especialista. Behlau M. São Paulo: Lovise; 2001. p. 226-7.

27. Rezende A, Guedes AP, Almeida C, Borrego MC, Behlau M, Pontes P, et al. Constrição ântero-posterior em indivíduos normais durante a fonação sustentada. Rev Soc Bras Fonoaudiol. 1998;2(4):22-8.

28. Steffen LM, Moschetti MB, Steffen N, Hanayama EM Paralisia unilateral de prega vocal: associação e correlação entre tempos máximos de fonação, posição e ângulo de afastamento. Rev Bras Otorrinolaringol. 2004;70(4):450- 


\section{Appendix}

Protocol of Speech Pathology cooperation for laryngeal mobility fiberoptic nasolaryngoscopy evaluation in thyroid diseases (PAN)

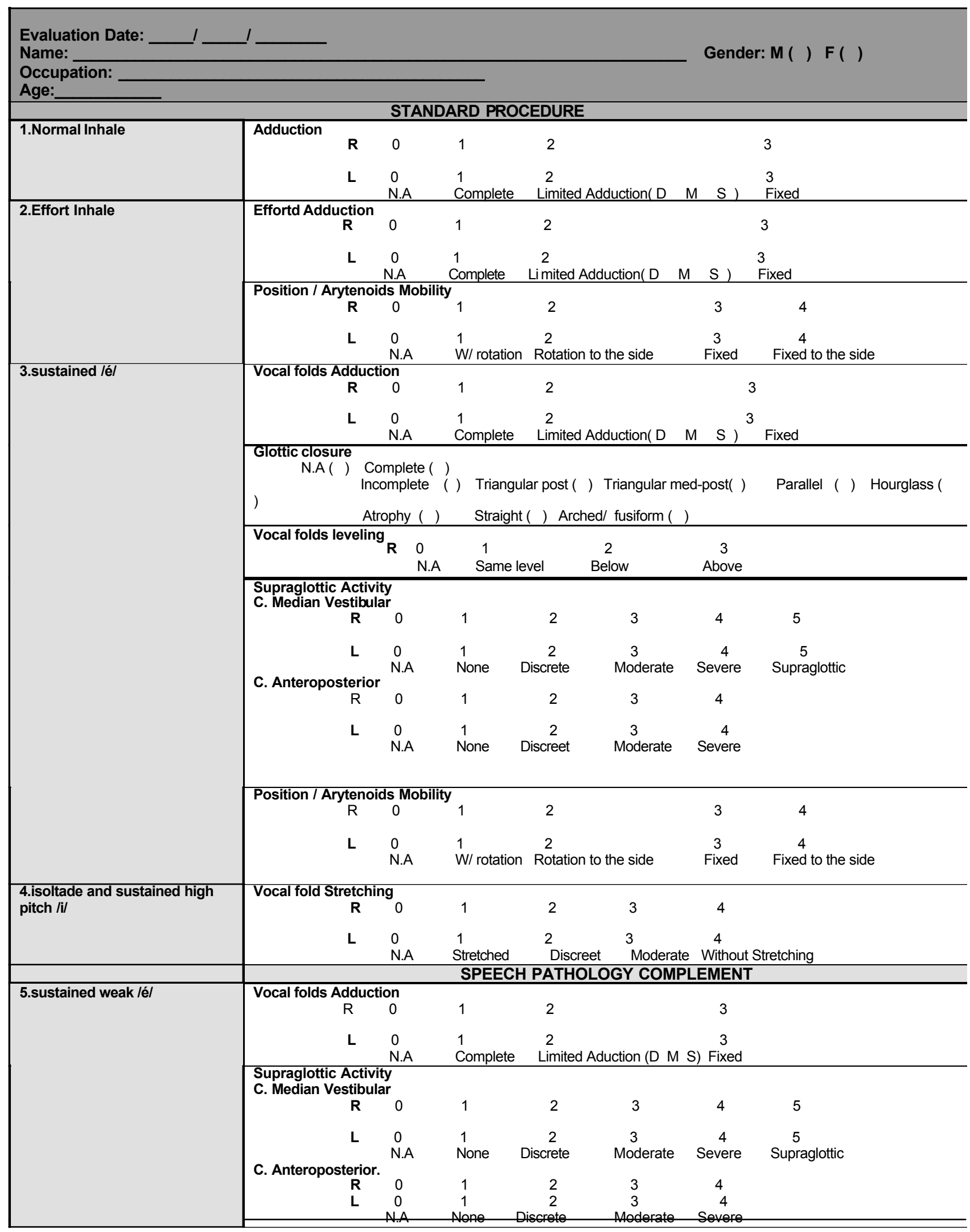




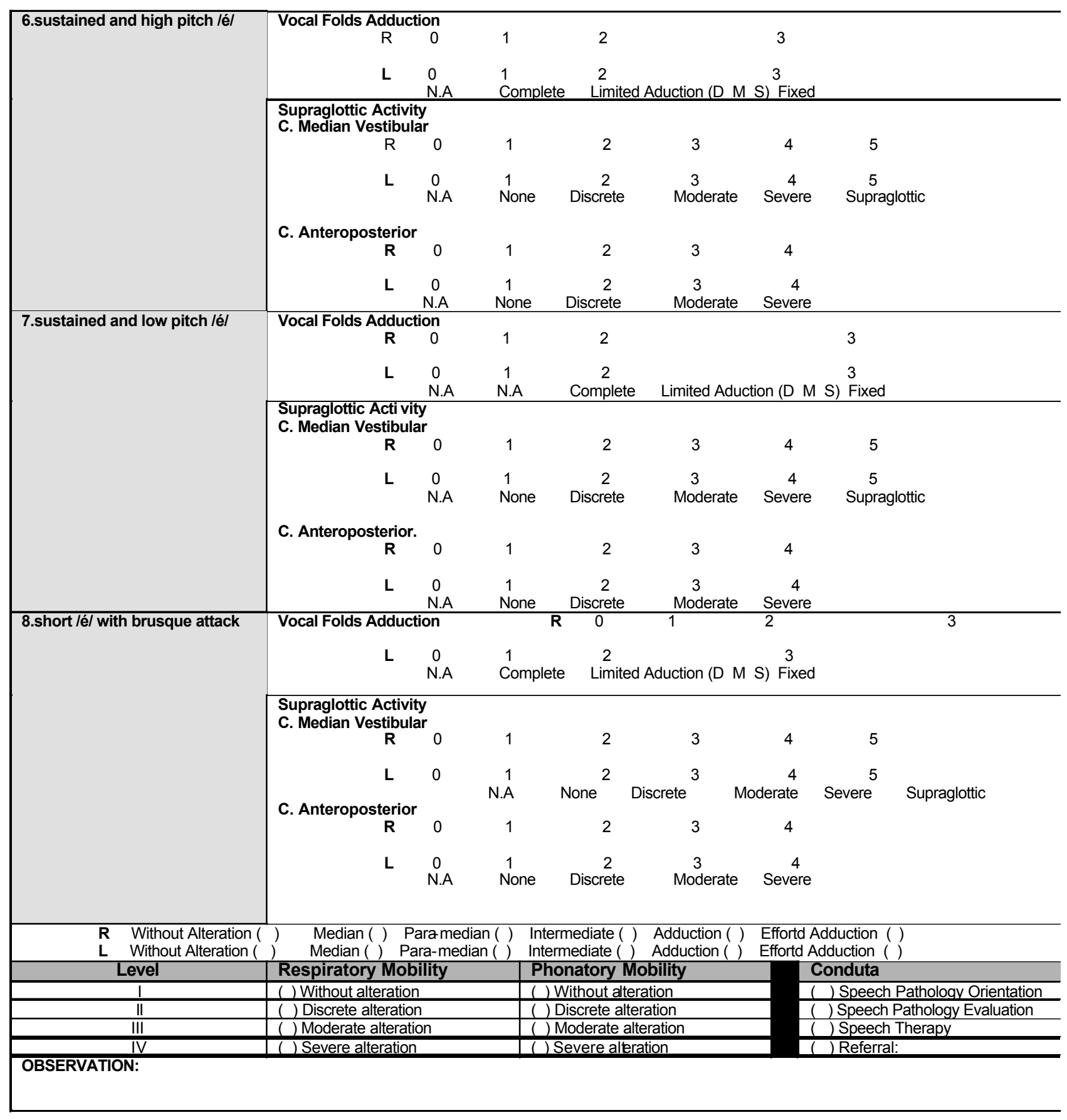

$N . A=$ not acessable $; C .=$ constriction $; D=$ Discreet; $M=$ Moderate; $S=$ Severe. $R=$ Right L=Left 